\title{
SPRÁVNÍ AKTY PODMIŇUJÍCÍ PRÁVNÍ JEDNÁNÍ
}

\author{
PAVEL KOPECKÝ
}

\begin{abstract}
Administrative Acts as a Condition of Juridical Acts
The author deals with the issue of administrative acts released by administrative authorities which entitle persons to make juridical act bringing legal effect in the area of private law. The author shows which provisions of laws prohibit to make juridical act without compulsory consent of administrative authority. By compulsory consent of administrative authority can be conditioned e.g. some contracts or decisions of general meeting in selected areas of public law regulation. The author analysis character of administrative acts which are condition of juridical acts and explains why public law regulates and limits juridical acts between persons of private law. The author further deals with individual consequences of juridical acts made without compulsory consent of administrative authorities as invalidity of juridical acts or administrative punishments.
\end{abstract}

Keywords: administrative act; juridical act; consent of administrative authority to juridical act

Klíčová slova: správní akty; právní jednání; souhlas správního orgánu s právním jednáním

DOI: $10.14712 / 23366478.2020 .13$

\section{1. ÚVODEM}

Mnohé normy veřejného práva podmiňují provedení určité činnosti vydáním správního aktu, kterým správní orgán takovou činnost dovoluje, př́padně stanovuje meze výkonu oné činnosti. Tyto správní akty můžeme souhrnně nazvat jako akty dovolující, úřední dovolení1 či opisně jako akty k dobru adresáta a současně pozitivní správní akty. ${ }^{2}$ Provozování činnosti, která je podmíněna vydáním dovolujícího správního aktu, bez takového aktu, má za následek její protiprávnost. ${ }^{3}$ Omezení určité činnosti veřejnoprávní regulací je pritom omezením sféry autonomie plynoucí z ústavního pravidla, že každý může činit vše, co není zakázáno. ${ }^{4}$ Potřeba veřejnoprávní regulace může být odůvodněna např́klad potřebou ochrany majetku, veřejného pořádku, lidského zdraví, tržního hospodářství atd.

Právní řád vydáním dovolujícího správního aktu podmiňuje řadu činností, které kvůli tomu není možné provádět volně, bez dalšího. Může jít např́klad o provádění stavby, řízení motorového vozidla, provozování koncesované živnosti, provozování hornické činnosti či zvláštní užívání lesa. V naprosté většině př́ípadů právní ŕád vydáním dovolu-

\footnotetext{
Viz HOETZEL, J. Československé správní právo. Praha: Melantrich, 1934, s. 248.

Viz KOPECKÝ, M. Správní právo. Obecná cást. Praha: C. H. Beck, 2019, s. 161.

Srov. HOETZEL, c. d., s. 248: „Jsou normy, které viži určité činnosti na úředni dovolení, spojujice s nimi, jestliže a protože byly provedeny bez tohoto dovolení, následky činu bezprávného."

4 Viz KOPECKÝ, c. d., s. 162.
} 
jícího správního aktu podmiňuje ty činnosti, které bychom mohli označit jako faktické. Ona faktická činnost vyvolává účinky ve vnějším světě, aniž by jí právo tyto účinky muselo přiznávat. Tímto možná poněkud komplikovaným vymezením se pokouším ukázat rozdíl mezi „,faktickou činnosti““ a právním jednáním, které zamýšlené účinky vyvolává právě a jen díky tomu, že mu je právní rád přiznává. Tento článek má ambici se věnovat právě př́padům, kdy veřejnoprávní normy podmiňují provedení určitého právního jednání, například uzavření smlouvy, vydáním dovolujícího správního aktu správním orgánem, bez něhož je provedení takového právního jednání v rozporu s právem.

Právní jednání je pojem, který byl do právního řádu zaveden občanským zákoníkem č. 89/2012 Sb. (OZ). Samotný pojem právní jednání, který nahradil zažitý pojem právní úkon, není v právním řádu definován, avšak jeho obsah je poměrně zřejmý. Podle definice z pražské učebnice občanského práva se právním jednáním rozumí takové chování osoby, které je schopno podle ustanovení objektivního práva vyvolat právní následky, tedy vznik, změnu či zánik práv a/nebo povinností. ${ }^{5}$ Typickým právním jednáním je např́íklad smlouva. Následky právního jednání mohou být obligační (např. vznik závazku) nebo věcněprávní (napr. přechod vlastnictví). Ovšem nikoliv každé chování, které je schopno podle ustanovení objektivního práva vyvolat právní následky, můžeme považovat za právní jednání. Chování, které vyvolává následky ve vertikálních veřejnoprávních vztazích (subjekt veřejné správy - adresát), se za právní jednání ve smyslu, v jakém ho užívá OZ, zpravidla nepovažuje. Právním jednáním v užším smyslu tedy není např́íklad podání návrhu na zahájení správního řízení či naplnění objektivní stránky přestupku, ačkoli takové chování vyvolává právní důsledky. K civilistické definici by se proto slušelo doplnit, že právní jednání je takové chování, které vyvolává právní následky v oblasti soukromého práva. Aby šlo o právní jednání, musí být zejména přítomna vưle jednající osoby právně jednat, která je projevena zjevně vážně. $V$ opačném př́ípadě jde o zdánlivé právní jednání, které nevyvolává žádné právní následky. ${ }^{6}$

Př́ípady, kdy je k provedení určitého soukromoprávního jednání normami veřejného práva vyžadován souhlas správního orgánu, nejsou v právním řádu př́liš časté, na druhou stranu však tyto prŕpady nejsou zcela neobvyklé a je třeba se jimi pro jejich specifičnost bliže zabývat. Správní akty, které opravňují jejich adresáty k provedení právního jednání, spojují dva oddělené, nikoliv však neprostupné světy - právo veřejné a právo soukromé. Oba systémy jsou pritom vybudovány na odlišných principech.

Jedním z ústředních principů občanského práva jakožto obecného soukromého práva je autonomie vůle, přičemž jedním z jejích projevů je smluvní svoboda. Soukromé právo tvoří právní normy, které upravují vzájemná práva a povinnosti osob. Správní akty podmiňující právní jednání znamenají určité narušení autonomie vůle i smluvní svobody a prostřednictvím nich vstupuje veřejná moc do soukromoprávních vztahů, když vrchnostensky rozhoduje, zda osoby, zpravidla soukromého práva, mohou v určitých př́padech právně jednat, či nikoli. Střet veřejného a soukromého práva lze demonstrovat i pomocí zájmové teorie, která napomáhá rozdělit právo na soukromé a veřejné. ${ }^{7}$

\footnotetext{
5 Viz DVOŘÁK, J. - ŠVESTKA, J. - ZUKLÍNOVÁ, M. a kol. Občanské právo hmotné. Svazek 1. Díl první: Obecná ćást. 2. vyd. Praha: Wolters Kluwer, 2016, s. 156.

Viz $§ 551$ a $552 \mathrm{OZ}$.

Viz KOPECKÝ, c. d., s. 10.
} 
Zatímco při právním jednání, které je upraveno předpisy soukromého práva, jeho strany sledují svůj soukromý zájem, správní orgán vázaný předpisy práva veřejného vyslovující souhlas s tímto právním jednáním primárně sleduje zájem veřejný. Právní jednání, které je perfektní a nezkracuje práva žádné z jeho stran, může být přesto nezákonné, a to pro rozpor s právem veřejným.

Správní akty podmiňující právní jednání musíme odlišovat od úkonů orgánů veřejné správy, zpravidla neregulativních, které jsou nutné $\mathrm{k}$ tomu, aby právní jednání nabylo účinků. $V$ tomto př́ípadě jde zejména o zápisy do veřejných rejstř́íků, např́íklad katastru nemovitostí, s kterými právní řád spojuje právní účinky právních jednání, přičemž samotné právní jednání nepodléhá žádnému veřejnoprávnímu dovolení. Tyto úkony jsou předvídány samotnými předpisy soukromého práva a právo veřejné pouze poskytuje právní rámec pro jejich provedení, zatímco správní akty podmiňující právní jednání zavádí právo veřejné bez užší vazby na právo soukromé.

Problematice správních aktů podmiňujících právní jednání není v odborné literatuře věnována téměř žádná pozornost, autoři se této skupině aktů věnují toliko v souvislosti $\mathrm{s}$ konkrétními ustanoveními právních předpisů, zejména v komentářové literatuře, nikoliv však v obecné rovině. Cílem tohoto článku je v prvé řadě upozornit na existenci této skupiny správních aktů, která se významně odlišuje od ostatních dovolujících správních aktů. V tomto článku se chci zabývat výskytem zkoumaného jevu v pozitivním právu, dále důvody, proč veřejná moc autoritativně vstupuje do právních jednání a také důsledky, které je možné spojovat s právním jednáním, které je provedeno bez souhlasu správního orgánu $\mathrm{v}$ případech, kdy je takový souhlas právními předpisy vyžadován.

\section{VÝSKYT V POZITIVNÍM PRÁVU}

Zkoumaný jev můžeme demonstrovat na několika prípadech z platného práva, kterým budeme věnovat pozornost i v dalším textu a na jejichž základě se následně pokusíme zkoumaný jev zobecnit.

\subsection{UST. § 16 ODST. 1 ZÁKONA O BANKÁCH}

Podle § 16 odst. 1 zákona č. 21/1992 Sb., o bankách (BankZ), musí mít banka předchozí souhlas České národní banky (ČNB) jako dohledového správního orgánu k uzavření smlouvy, na jejímž základě dochází k jakékoliv dispozici s obchodním závodem nebo jeho částí, ${ }^{8} \mathrm{k}$ rozhodnutí valné hromady o zrušení banky, $\mathrm{k}$ fúzi nebo

8 Pojem obchodní závod je vymezen v $\$ 502$ OZ. Podle tohoto ustanovení je obchodní závod organizovaný soubor jmění, který podnikatel vytvořil a který z jeho vủle slouží k provozování jeho činnosti. Má se za to, že závod tvoří vše, co zpravidla slouží $\mathrm{k}$ jeho provozu. Koupí závodu se kupující stává věřitelem pohledávek a dlužníkem dluhů, které $\mathrm{k}$ závodu náleží; z dluhů však kupující přejímá jen ty, o jejichž existenci věděl nebo ji alespoň musel rozumně předpokládat (§ $2177 \mathrm{OZ})$. Koupě závodu se považuje za převod činnosti zaměstnavatele $\$ 2175$ odst. $2 \mathrm{OZ}$ ), na kupujícího přechází všechny věci tvořící obchodní závod, včetně nemovitých, i např́íklad klientela. Je-li kupující zapsán ve veřejném rejstř́iku, nabývá vlastnické právo $\mathrm{k}$ závodu jako celku zveřejněním údaje, že uložil doklad o koupi závodu do sbírky listin podle zákona o veřejných rejstř́icích. Není-li kupující zapsán do veřejného rejstř́íku, nabývá vlastnické právo k závodu jako celku účinností smlouvy (§ 2180). 
rozdělení banky nebo převodu jmění na banku jakožto společníka, ke snížení základního kapitálu banky nebo k rozhodnutí valné hromady o tom, že již nebude vykonávat činnosti, ke kterým je třeba bankovní licence.

BankZ v $\S 16$ odst. 1 vymezuje i okruh účastníků řízení o udělení předchozího souhlasu. Tím je zásadně pouze žádající banka; účastníky tohoto ř́zení jsou však rovněž druhá smluvní strana při dispozici s obchodním závodem nebo jeho částí, další zúčastněné akciové společnosti při fúzi nebo rozdělení anebo přejímající společník při př̀vodu jmění.

\subsection{UST. § 19 ZÁKONA O PODNIKÁNÍ NA KAPITÁLOVÉM TRHU}

Podobná úprava se nachází také v zákoně č. 256/2004 Sb., o podnikání na kapitálovém trhu (ZPKT). Podle § 19 tohoto zákona je souhlas ČNB třeba k přeměnám obchodníka (fúze, rozdělení, změna právní formy obchodníka s cennými papíry, převod jmění na společníka nebo převod jmění jiné osoby na obchodníka s cennými papíry). Podle $\S 20$ ZPKT je povolení ČNB třeba k uzavření smlouvy o prevodu, zastavení nebo o pachtu obchodního závodu obchodníka s cennými papíry nebo části takového obchodního závodu, která by znamenala podstatnou změnu v jeho činnosti. Zde můžeme upozornit na terminologickou nejednotnost zákona, když v jednom prŕpadě (§ 19) používá termín souhlas a v druhém případě (\$ 20) povolení, ačkoli oba správní akty jsou materiálně souhlasem a k jejich odlišování není důvod.

\subsection{UST. § 20 ZÁKONA O BANKÁCH}

Další př́iklad můžeme nalézt opět v BankZ. Ten v $§ 20$ odst. 3 stanoví, že osoba nebo osoby jednající ve shodě musejí mít souhlas ČNB k nabytí kvalifikované účasti na bance, ke zvýšení kvalifikované účasti na bance tak, že dosáhne nebo překročí $20 \%, 30 \%$ nebo $50 \%$, nebo k tomu, aby se staly osobami ovládajícími banku. Nabytí účasti v bance sice samo o sobě není právním jednáním, avšak právním titulem, na jehož základě dochází k nabytí účasti v bance, je zpravidla právní jednání. Souhlas ČNB by dle mého názoru měl tomuto právnímu jednání předcházet, př́ípadně by mělo být právní jednání učiněno s odkládací podmínkou vázanou na souhlas ČNB. Výjimkou jsou př́ipady, kdy k nabytí účasti vedou jiné právní skutečnosti (např. smrt akcionáře, kde je právním titulem pořízení pro př́ípad smrti či zákon). Osoba, která bez předchozího souhlasu ČNB nabude nebo zvýší kvalifikovanou účast na bance nebo ji ovládne, je povinna neprodleně ČNB o této skutečnosti informovat a bez zbytečného odkladu ji požádat o souhlas. ${ }^{9}$ Souhlas lze v př́ípadech zvláštního zřetele hodných udělit i následně. $\mathrm{K}$ tomu může dojít např́íklad $\mathrm{v}$ př́ípadě dědění podílu nebo $\mathrm{v}$ případě nabytí podílu na kapitálových trzích. ${ }^{10}$ Obdobně je třeba žádat ČNB o souhlas s nabytím kvalifikované účasti v pojišt’ovně podle § 24 zákona č. 277/2009 Sb., o pojišt'ovnictví (PojZ).

9 Viz $\S 20$ odst. 11 BankZ.

10 Viz LIŠKA, P. - DŘEVÍNEK, K. - KOTÁB, P. - RÝDL, T. Zákon o bankách. Komentár. Praha: Wolters Kluwer, 2016, s. 242. 


\subsection{UST. § 21 ODST. 6 A 7 ZÁKONA O PROVOZOVÁNÍ ROZHLASOVÉHO A TELEVIZNÍHO VYSÍLÁNÍ}

V některých rysech podobná úprava se nachází i v zákoně č. 231/2001 Sb., o provozování rozhlasového a televizního vysílání (ZRTV). Ten v $§ 21$ odst. 6 stanoví, že provozovatel rozhlasového vysílání s licencí, který je právnickou osobou, nebo jeho společník může po předchozím souhlasu Rady pro rozhlasové a televizní (RRTV) vysílání převádět na třetí osoby podíl ve společnosti provozovatele rozhlasového vysílání s licencí. Podle téhož ustanovení rada souhlas neudělí pouze tehdy, pokud by došlo k omezení plurality informací podle $\S 55$ a 56 zákona. Totéž platí i pro provozovatele televizního vysílání. Poněkud nelogické je, že ZRTV uvádí, že by se souhlasem RRTV mohl podíl převádět i provozovatel vysílání, který je právnickou osobou, tedy že by sama právnická osoba převáděla svůj vlastní podíl. Oproti zákonu o bankách nebo zákonu o pojišt’ovnictví není souhlas správního orgánu vyžadován k nabytí účasti ve společnosti, ale naopak $\mathrm{k}$ převodu účasti ve společnosti na třetí osobu.

\subsection{UST. § 13 ZÁKONA O OCHRANĚ HOSPODÁŘSKÉ SOUTĚŽE}

Svébytnou oblastí, kde můžeme též narazit na zkoumaný jev, je ochrana hospodářské soutěže. Podle zákona č. 143/2001 Sb., o ochraně hospodářské soutěže (ZOHS), podléhá povolení Úřadu na ochranu hospodářské soutěže (ÚOHS) spojování soutěžitelů ${ }^{11}$, jejichž obrat dosahuje určité hodnoty. ${ }^{12}$ Ke spojení soutěžitelů dochází fúzí dvou nebo více na trhu dříve samostatně působících soutěžitelů. Za spojení soutěžitelů se dále považuje, pokud jeden nebo více podnikatelů anebo jedna nebo více osob, které nejsou podnikateli, ale kontrolují alespoň jednoho soutěžitele, získá možnost přímo či nepřímo kontrolovat jiného soutěžitele nebo jeho část, zejména nabytím účastnických cenných papírů, obchodních nebo členských podílů anebo smlouvou nebo jinými způsoby, které jim umožňují takového soutěžitele nebo jeho část kontrolovat. ${ }^{13}$ Ke spojování soutěžitelů tak může dojít např́klad i nabytím obchodního závodu jiného soutěžitele. ${ }^{14}$ Ke spojování soutěžitelů zásadně dochází na základně právních jednání, povolení ÚOHS primárně nepodléhá toto právní jednání, ale až jeho následky, čili spojení soutěžitelů. Přestože ke spojení soutěžitelů může dojít i fakticky, domnívám se, že povolení ÚOHS ke spojení soutěžitelů můžeme zařadit do skupiny správních aktů podmiňujících právní jednání, nebot' bez povolení ÚOHS nemůže legálně docházet ke spojování soutěžitelůำ a právní jednání je typickým právním důvodem spojování soutěžitelů. Ze všech uvedených př́padů obsahuje zákon o ochraně hospodářské soutěže nejpodrobnější úpravu řízení, nejpropracovanější je i úprava řešící jednání v rozporu

11 Soutěžiteli se podle ZOHS rozumí fyzické a právnické osoby, jejich sdružení, sdružení těchto sdružení a jiné formy seskupování, a to i v případě, že tato sdružení a seskupení nejsou právnickými osobami, pokud se účastní hospodářské soutěže nebo ji mohou svou činností ovlivňovat, i když nejsou podnikateli.

12 Viz $\S 13$ ZOHS.

13 Viz $\S 12$ odst. 1 ZOHS.

14 Viz ČERNÁ, S. a kol. Obchodní právo: podnikatel, podnikání, závazky s účastí podnikatele. Praha: Wolters Kluwer, 2016, s. 276.

15 Viz $§ 18$ odst. 1 ZOHS. 
S rozhodnutím správního orgánu, které budeme věnovat pozornost v dalších částech textu.

\section{POVAHA SPRÁVNÍCH AKTU゚ PODMIŇUJÍCÍCH PRÁVNÍ JEDNÁNÍ, PROCESNÍ REŽIM}

Správní akty obecně jsou zřejmě nejtypičtější formou správní činnosti. Správní akty lze pak dále členit podle různých kritérií na více druhů. ${ }^{16} \mathrm{Na}$ tomto místě se můžeme pokusit zařadit i správní akty, kterými právní normy podmiňují provedení některých právních jednání. Jde přitom o určité zobecnění vycházející z výskytu v platném právu, které nemusí být všeobjímající. Některé správní akty se tak mohou tomuto rozčlenění vymykat.

Správní akty podmiňující právní jednání mají konstitutivní povahu, oprávnění provést právní jednání vzniká až právní mocí takového rozhodnutí. Tyto akty se vztahují $\mathrm{k}$ určité osobě, nikoli předmětu, jedná se tedy o správní akty in personam. Zkoumané akty jsou tzv. materiálními správními akty, nebot' mají vliv na hmotná subjektivní práva adresátů.

Při rozhodování o udělení souhlasu s právním jednáním nebývá správním orgánům ponechán prostor pro správní uvážení (viz např. § 21 odst. 6 ZRTV „Rada souhlas neuděli pouze tehdy, pokud by došlo k omezení plurality informací podle $\$ 55$ a $56^{\prime \prime}$ nebo $§ 20$ odst. 4 BankZ: „Česká národní banka žádosti vyhoví, pokud z hlediska možného vlivu na výkon činnosti banky jsou splněny tyto podmínky [...]“). Správní orgány však při zkoumání, zda jsou naplněny podmínky pro udělení souhlasu, musí vykládat neurčité právní pojmy (viz např. § 20 odst. 4 písm. b) BankZ: „Osoby, které jsou navrhovány za členy statutárního orgánu, členy správní rady, členy dozorči rady a osoby ve vrcholném vedení banky [...] splñuji bez zjevných pochybností podmínku důvěryhodnosti, odborné způsobilosti a zkušenosti" ${ }^{\prime \prime}$ ). V některých případech ale zákon nestanoví žádné podmínky, které by měl správní orgán při rozhodování zkoumat (viz např. $§ 20$ odst. 1 ZPKT). To považuji za chybu, nebot' správní orgán nemá při rozhodování žádné zákonné vodítko, zda žádosti vyhovět či nikoli, a hrozí, že jeho rozhodnutí bude nepřezkoumatelné. Vzhledem k nepřípustnosti zcela neomezeného správního uvážení musí $\mathrm{v}$ těchto př́ípadech správní orgány žádosti poměřovat s účelem a smyslem norem, které souhlas vyžadují. Obecně však lze říci, že na udělení souhlasu má žadatel zásadně právní nárok, pokud jsou splněny všechny požadavky, které zákon pro udělení souhlasu stanoví.

Z typizovaných správních aktů můžeme správní akty podmiňující právní jednání, bez ohledu na jejich legální označení, podřadit pod pojem souhlas nebo povolení, a to v závislosti na tom, zda správní orgán může stanovit podmínky, za jakých může být právní jednání provedeno.

Rozhodování o udělení souhlasu s provedením právního jednání subsidiárně podléhá procesnímu režimu správního řádu, tzn. o udělení či neudělení souhlasu správní orgán

16 Viz např. KOPECKÝ, c. d., s. 154. 
rozhoduje ve správním řízení a výsledné správní akty mají vnější formu rozhodnutí ve smyslu § 67 správního řádu. Řízení o udělení souhlasu k právnímu jednání je možné z logiky věci zahájit pouze na žádost, nikoli z moci úřední.

\section{OPODSTATNĚNÍ SPRÁVNÍCH AKTŮ PODMIŇUJÍCÍCH PRÁVNÍ JEDNÁNÍ}

Jak bylo uvedeno již v úvodu, dle pravidla zakotveného v čl. 2 odst. 3 Listiny základních práv a svobod může každý činit to, co není zákonem zakázáno. Každé zákonné zúžení autonomní sféry musí být proporcionální a musí obstát $\mathrm{v}$ testu ústavnosti. Veřejnoprávní regulaci podléhají činnosti, které by, nebýt této regulace, bylo možné vykonávat volně. ${ }^{17}$ Stejně je tomu u právních jednání, která jsou veřejným právem podmíněna vydáním dovolujícího správního aktu. Bez veřejnoprávního omezení by tato právní jednání bylo možné činit volně v mantinelech stanovených právem soukromým, které s právním jednáním spojuje následky právním jednáním sledované. Jako omezení každé činnosti musí být veřejnoprávní omezení právního jednání proporcionální a musí sledovat legitimní cíl. Musíme si uvědomit, že podmiňování právního jednání správními akty je veřejnoprávním zásahem do oblasti práva soukromého, které je vybudováno na principu autonomie vůle.

Výše uvedené př́íklady naznačují, že správní akty podmiňující právní jednání se objevují zejména v odvětvích, pro která je typická silná veřejnoprávní regulace, jako je bankovnictví, pojišt'ovnictví, finanční trhy, rozhlasové a televizní vysílání atd. V těchto odvětvích je právem omezen př́stup na trh, a to např́íklad z důvodu vysokých provozních požadavků u bank a pojištoven nebo určité omezenosti zdrojů v př́ipadě pozemního rozhlasového a televizního vysílání. Subjekty působící v těchto regulovaných odvětvích musí splňovat určitou míru důvěryhodnosti a jejich chování musí být předvídatelné. $\mathrm{Z}$ tohoto důvodu je $\mathrm{k}$ podnikání $\mathrm{v}$ uvedených oblastech vždy vyžadováno veřejnoprávní oprávnění - licence, která je udělována př́slušnými správními orgány ve správním ř́zení.

Veřejnoprávní regulace a omezení vstupu na trh je v těchto odvětvích kromě omezených zdrojů odůvodnitelná např́klad potřebou stability finančních trhů a ochranou věřitelů u finančních institucí nebo ochranou veřejné mravnosti a potřebou vyváženého a objektivního informování u provozovatelů rozhlasového a televizního vysílání.

Při řízení o udělení oprávnění správní orgán posuzuje splnění určitých podmínek, bez jejichž naplnění není možné př́ślušné oprávnění k provozování regulované činnosti udělit. Např́iklad podle BankZ pro udělení bankovní licence musí být splněna důvěryhodnost a kvalifikace osob $\mathrm{s}$ kvalifikovanou účastí na bance, ${ }^{18}$ podle ZRTV při rozhodování o udělení licence RRTV hodnotí transparentnost vlastnických vztahů ve společnosti žadatele. ${ }^{19}$

\footnotetext{
Srov. KOPECKÝ, c. d., s. 162.

8 Viz $§ 4$ odst. 5 BankZ.

19 Viz. § 17 odst. 1 ZRTV.
} 
Význam správních aktů podmiňujících právní jednání může spočívat v tom, že zabraňují obcházení zákona v řízeních o udělení licence. Souhlasem správního orgánu jsou podmiňována ta právní jednání, kterými dochází ke změnám charakteru regulovaného subjektu, jako je rozhodnutí nejvyššího orgánu obchodní korporace o přeměně, dispozice s podílem, obchodním závodem či jeho podstatnou částí. Podmínění určitých právních jednání souhlasem správního orgánu má zamezit tomu, aby na straně regulovaných subjektů docházelo k takovým změnám, pro které by jinak oprávnění nemohlo být uděleno.

Jakkoli je např́iklad důvěryhodnost neurčitý právní pojem, lze si typicky představit, že po udělení licence bance důvěryhodný akcionář s kvalifikovanou účastí převede svou účast v bance na „,nedůvěryhodnou“ osobu, která by původně byla důvodem pro neudělení oprávnění a která tím získá kvalifikovanou účast.

Nutný souhlas dohledového orgánu k některým právním jednáním by také měl zaručit stabilitu finančního trhu a solventnost regulovaných subjektů na finančních trzích. V těchto regulovaných odvětvích je podmiňování určitých právních jednání legitimní ze stejných důvodů, jako je legitimní podmiňovat vstup na trh udělením licence.

Dalším př́ikladem správního aktu podmiňujícího právní jednání je povolení ÚOHS ke spojování soutěžitelů. I v oblasti ochrany hospodářské soutěže je požadavek předchozího souhlasu správního orgánu s právním jednáním snadno odůvodnitelný. Povolení ÚOHS k spojování soutěžitelů má preventivní roli a chrání existenci volné hospodářské soutěže.$^{20}$ Povolení navíc nepodléhají všechna spojení, ale pouze ta, která mohou hospodářskou soutěž narušit. Kritériem je výše obratu spojujících se soutěžitelů.

\section{NEDOSTATEK SOUHLASU SPRÁVNÍHO ORGÁNU K PRÁVNÍMU JEDNÁNÍ A JEHO DŮSLEDKY}

\subsection{OBECNĚ K NEDOSTATKU SOUHLASU}

V řízení o udělení souhlasu s právním jednáním může správní orgán meritorně rozhodnout $\mathrm{v}$ zásadě dvěma způsoby: Rozhodnutím udělí žadateli (žadatelům) souhlas s provedením právního jednání, např. povolí zcizení obchodního závodu nebo nabytí kvalifikované účasti v bance, anebo žádost zamítne. Je-li před provedením právního jednání podána žádost o souhlas a následně je postupováno v souladu s pravomocným rozhodnutím, je vše $\mathrm{v}$ pořádku. Pokud správní orgán vydal souhlas s právním jednáním v souladu s právními předpisy, kterými je při rozhodování vázán, a toto právní jednání bylo po nabytí právní moci provedeno v souladu s předpisy soukromého práva, je takové právní jednání platné a jeho stranám přinese předpokládané účinky - pro právní vědu je tato situace, zdá se, dále již nezajímavá.

O poznání zajímavější situace nastává, pokud je právní jednání provedeno bez souhlasu př́islušného správního orgánu, a to zejména tak, že bylo právní jednání provedeno, ačkoli žádost o udělení souhlasu byla zamítnuta, anebo o udělení souhlasu vủbec nebylo požádáno a žádné řizení nebylo zahájeno. Provedení právního jednání přes nedosta-

20 Viz ČERNÁ, c. d, s. 269. 
tek souhlasu př́islušného správního orgánu v každém případě znamená protiprávnost takového právního jednání. Otázkou je, zda a případně jaké důsledky může protiprávnost právního jednání znamenat. Důsledky protiprávnosti můžeme rozdělit na důsledky veřejnoprávní a soukromoprávní. Nutno zdůraznit, že vždy jde o důsledky porušení veřejného, nikoli soukromého práva. Přestože slovní spojení neoprávněné či protiprávní právni jednání může na první pohled vypadat jako oxymóron až nesmysl, je v něm přesně vystižena podstata problému nedostatku souhlasu správního orgánu.

Mezi veřejnoprávní důsledky můžeme zařadit zejména uložení správního trestu, odebrání veřejnoprávního oprávnění nebo uložení nápravných opatření. Jako o soukromoprávních důsledcích můžeme uvažovat o neplatnosti či neúčinnosti právního jednání, př́padně o zákazu výkonu určitých soukromých práv, napřr. výkon hlasovacích práv. ${ }^{21}$

Jak si ukážeme na následujících příkladech z platné právní úpravy, zákonodárce k řešení nedostatku souhlasu správního orgánu přistupuje zcela nesystematicky a v podobných př́ipadech volí rozdílná řešení. Uvedené příklady navazují na prríklady uvedené v předchozí části textu.

\subsection{DŮSLEDKY PORUŠENÍ § 16 BANKZ}

V § 16 odst. 1 BankZ stanoví, že právní jednání a usnesení valné hromady učiněná bez požadovaného předchozího souhlasu jsou neplatná. Toto ustanovení se týká právních jednání provedených bez souhlasu ČNB, která souvisejí se samotnou existencí banky, jako je dispozice s obchodním závodem, zrušení banky, její fúze či rozdělení.

Na tomto místě považuji za vhodné učinit exkurz týkající se neplatnosti právních jednání. Neplatnost je negativní následek právního jednání, ke kterému dochází v důsledku vady právního jednání, která spočívá v nedostatku některé náležitosti, kterou zákon pro právní jednání stanoví. ${ }^{22}$ Neplatnost právního jednání obecně upravuje $§ 574$ a násl. občanského zákoníku. Občanský zákoník stanoví, že neplatné je právní jednání, které se příčí dobrým mravům, jakož i právní jednání, které odporuje zákonu, pokud to smysl a účel zákona vyžaduje - toto je však pouze jeden z důvodů neplatnosti, zákon může stanovit i jiné, zvláštní důvody neplatnosti, které jsou ve vztahu speciality k obec-

21 „Starý“ občanský zákoník č. 40/1964 Sb. (OZ 64) obsahoval v § 47 odst. 1 následující ustanovení: „Jestliže zákon stanoví, že ke smlouvě je třeba rozhodnutí př́islušného orgánu, je smlouva účinná tímto rozhodnutím.“ Odst. 2. téhož paragrafu stanovil: „Nebyl-li podán do tři let od uzavření smlouvy návrh na rozhodnutí podle odstavce 1, platí, že účastníci od smlouvy odstoupili." Současný občanský zákoník žádné podobné ustanovení neobsahuje. Při pouhém gramatickém výkladu bychom mohli dojít k závěru, že tato ustanovení se vztahovala na případy, které rozebírány v tomto článku. Novější (rozuměj porevoluční) komentáře ke starému občanskému zákoníku shodně považují toto ustanovení za obsoletní: „Za současného právního stavu nelze najít ani jeden př́pad, na který by se \$ 47 vztahoval. Zachováni jeho existence po roce 1991 je tedy pro adresáty právní normy značně matoucí, ustanovení je však ve skutečnosti obsoletní a nic neupravuje.“ (viz FIALA, J. - KINDL, M. a kol. Občanský zákoník. Komentář. I. díl. Praha: Wolters Kluwer, 2009, s. 273; podobně též § 47 In: JEHLIČKA, O. - ŠVESTKA, J. - ŠKÁROVÁ, M. a kol. Občanský zákoník. Komentář. 9. vyd. C. H. Beck, 2004, s. 271-274). Je nepochybné, že z předpisů občanského práva byla vypuštěna všechna ustanovení z dob totality, která vázala právní jednání na souhlas správního orgánu, je však otázkou, zda autoři, kteří prohlašovali § 47 OZ64 za obsoletní, měli povědomí o normách veřejného práva, které byly zavedeny po roce 1991 a určitá soukromoprávní jednání spojují se souhlasem správního orgánu, či tyto normy vůbec nebrali v úvahu.

22 Viz DVOŘ́K - ŠVESTKA - ZUKLÍNOVÁ, c. d., s. 188. 
ným důvodům neplatnosti. Rozlišujeme neplatnost relativní a absolutní. Je-li neplatnost právního jednání stanovena na ochranu zájmu určité osoby, jde o neplatnost relativní a námitku neplatnosti může vznést jen tato osoba. Nenamítne-li oprávněná osoba neplatnost relativně neplatného právního jednání, považuje se právní jednání za platné. ${ }^{23}$ Absolutně neplatné je právní jednání, které se zjevně prríči dobrým mravům, anebo které odporuje zákonu a zjevně narušuje veřejný pořádek. $V$ takovém př́padě soud přihlédne $\mathrm{k}$ neplatnosti právního jednání i bez návrhu. Zatímco $\mathrm{v}$ př́padě relativní neplatnosti má rozhodnutí soudu konstitutivní charakter, v př́padě absolutní neplatnosti je rozhodnutí soudu jen deklaratorní, absolutní neplatnost nastává bez dalš́ho, soud ji pouze zjistí. ${ }^{24}$ Ačkoli absolutní neplatnost nastává od počátku, deklarovat ji může pouze soud (civilní).

$\mathrm{V} \S 16$ odst. 1 zákon o bankách hovoří o právním jednání a usnesení valné hromady. Usnesení valné hromady akciové společnosti je zvláštním případem právního jednání a může být postiženo různými vadami včetně neplatnosti. Neplatnost usnesení valné hromady se však neřídí obecnými pravidly neplatnosti právních jednání, ale zvláštní úpravou v zákoně o obchodních korporacích. ${ }^{25}$ Neplatnosti usnesení valné hromady se může dovolávat každý akcionář, člen představenstva, dozorčí nebo správní rady nebo likvidátor pro rozpor s právními předpisy nebo stanovami. Výše řečené obdobně platí i pro rozhodování nejvyšších orgánů jiných typů obchodních společností. Neplatnost usnesení valné hromady opět může prohlásit pouze soud.

Je otázkou, zda právní jednání dle $§ 16$ odst. 1 zákona o bankách učiněné bez souhlasu je neplatné relativně či absolutně. Např́klad Š. Elek se ve svém komentáři k předmětnému ustanovení přiklání spíše k neplatnosti relativní. ${ }^{26}$ Pro absolutní neplatnost, jak ji vymezuje $\mathrm{OZ}$, by muselo kromě porušení zákona dáno i narušení veřejného pořádku. Můj názor je, že právní jednání bez vyžadovaného souhlasu ČNB by znaky narušení veřejného pořádku naplňovat mohlo. Oproti komentáři se však nedomnívám, že by neplatnost plynula primárně z obecného ustanovení § $580 \mathrm{OZ}$, nebot' neplatnost vyplývá přímo $\mathrm{z}$ př́slušného ustanovení zákona o bankách. ${ }^{27} \mathrm{~V}$ každém případě předmětná právní úprava s sebou přináší řadu problémů. Relativní neplatnosti by se musela dovolat osoba, na jejíž ochranu je právní neplatnost stanovena. Je otázkou, zda $\mathrm{v}$ případě relativní neplatnosti by se neplatnosti právního jednání mohla dovolávat sama ČNB. Domnívám se, že nikoli, nebot' ČNB není osobou, na jejíž ochranu je v tomto př́padě stanovena. Neplatnost je zde stanovena zejména $z$ dủvodu ochrany veřejného zájmu, nikoli z důvodu ochrany ČNB. Situace však není o nic jednodušší, pokud dovodíme narušení veřejného pořádku, a tím pádem neplatnost absolutní. Tu může též prohlásit pouze soud, ČNB jako správní orgán takovou pravomocí nedisponuje. Na právní jednání je navíc třeba spíše hledět jako na platné než jako na neplatné. ${ }^{28}$ Jak relativní, tak absolutní neplatnost může soud prohlásit pouze v občanském soudním řízení, které se zahajuje na návrh (žalobou). Strany neplatného právního jednání zřejmě nebudou mít zájem podávat návrh na zahájení rízení, aby soud právní jednání za neplatné autorita-

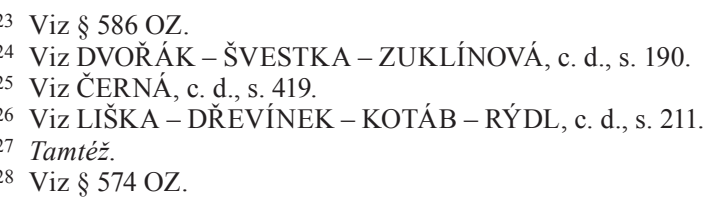


tivně prohlásil, a ČNB, která je dohledovým orgánem, dle mého názoru není aktivně legitimovaná, aby proti stranám neplatného právního jednání podala žalobu. Dalším problematickým aspektem je, že otázka platnosti či neplatnosti právního jednání je otázkou soukromého práva, neplatnost podle $\S 16$ odst. 1 zákona o bankách je sankcí za porušení normy veřejného práva - má snad civilní soud rozhodovat o sankcích za porušení veřejného práva? Podobně je to s neplatností usnesení valné hromady banky - té se podle $\S 428$ zákona č. 90/2012 Sb., o obchodních korporacích, (ZOK) může dovolat pouze taxativně vymezený okruh osob, mezi které ČNB rozhodně nepatří. V př́padě, že je banka ovládána jedním nebo několika málo akcionáři, se nemusí najít nikdo, kdo by se neplatnosti domáhal. S ohledem na výše řečené se domnívám, že neplatnost stanovená $\mathrm{v} \S 16$ odst. 1 je $\mathrm{v}$ praxi těžko aplikovatelná, a to zejména $\mathrm{z}$ důvodů kompetenčních.

Důsledky, které je možné spojovat s nedostatkem souhlasu správního orgánu k právnímu jednání, jsme si rozdělili na soukromoprávní a veřejnoprávní. Soukromoprávním důsledkem je $\mathrm{v}$ tomto př́padě výše rozebraná neplatnost. BankZ však s porušením $\S 16$ odst. 1 nečekaně nespojuje žádné veřejnoprávní důsledky, a to i přesto, že zákon o bankách jako přestupek poměrně kazuisticky kvalifikuje celou řadu jednání, která jsou v rozporu s jeho ustanoveními. Jednání bez souhlasu ČNB v př́ípadech uvedených $\mathrm{v} \S 16$ odst. 1 tedy není přestupkem (a ani jiným správním deliktem).

\subsection{DU゚SLEDKY PORUŠENÍ §§ 19 A 20 ZPKT}

Úprava v ZPKT je podobná té v BankZ. Zákon vyžaduje souhlas ČNB v pro podobný okruh právních jednání jako § 16 odst. 1 BankZ - přeměny obchodníka s cennými papíry a dispozice s obchodním závodem nebo jeho podstatnou částí. Právní úprava podle zákona o podnikání na kapitálovém trhu se však liší v jednom podstatném detailu - právní jednání bez souhlasu ZPKT nepovažuje za neplatné, respektive v otázce platnosti či neplatnosti mlčí. Př́ípadnou neplatnost právního jednání učiněného bez souhlasu ČNB můžeme dovozovat pouze z obecné úpravy v občanském zákoníku: „Neplatné je právní jednání, které se př̌či dobrým mravům, jakož i právní jednání, které odporuje zákonu, pokud to smysl a účel zákona vyžaduje“ (§ 580 odst. 1 OZ). Ne každé právní jednání, které je v rozporu se zákonem, je neplatné. Je otázka, zda v tomto př́ípadě smysl a účel zákona vyžaduje, aby jednání bez souhlasu ČNB bylo neplatné, př́padně kdo a jak by se neplatnosti mohl domáhat.

Stejně jako zákon o bankách zákon s porušením $§ 19$ a 20 nespojuje žádné veřejnoprávní důsledky.

\subsection{DŮSLEDKY PORUŠENÍ § 20 ODST. 3 BANKZ}

Oproti předchozímu př́ikladu BankZ přistupuje odlišně k právním jednáním, kterými se nabývá či zvyšuje kvalifikovaná účast v bance či se jimi banka ovládá a ke kterým, respektive $\mathrm{k}$ jejich účinkům, je podle $§ 20$ odst. 3 BankZ vyžadován souhlas.

V § 20 odst. 3 BankZ stanoví, že nabytí nebo zvýšení kvalifikované účasti na bance nebo její ovládnutí bez předchozího souhlasu České národní banky nemá za následek 
neplatnost právního jednání, na základě kterého $\mathrm{k}$ těmto změnám v účastech na bance došlo, avšak hlasovací práva spojená s takto nabytou účastí nesmějí být vykonávána, a to do doby udělení tohoto souhlasu.

BankZ však jde v otázce důsledků nedostatečného souhlasu podle $\S 20$ odst. 3 ještě dál. $\mathrm{V} \S 20$ odst. 1 zákon stanoví, že $\mathrm{v}$ př́ípadech, kdy účast na bance byla nabyta bez předchozího souhlasu ČNB podle $\S 20$ odst. 3 nebo po lhůtě k podle $\S 20$ odst. 14 a nebyl udělen následný souhlas podle $\S 20$ odst. 12 , a dále v př́padech, kdy osoba nesplní oznamovací povinnost podle $\S 20$ odst. 11 nebo ČNB zjistí, že působení osoby nebo osob s kvalifikovanou účastí na bance je na újmu řádnému a obezřetnému podnikání banky, popřípadě lze takové působení důvodně očekávat, ČNB ve správním řízení pozastaví majiteli akcií, který má sám nebo jednáním ve shodě s jinou osobou kvalifikovanou účast na bance, výkon následujících akcionářských práv: a) účastnit se a hlasovat na valné hromadě, b) požádat o svolání valné hromady.

Téže ustanovení dále stanoví, že pozastavit lze pouze výkon všech uvedených práv a že podání opravného prostředku proti rozhodnutí o pozastavení akcionářských práv nemá odkladný účinek. Toto ustanovení se překrývá s $§ 20$ odst. 3 , na jehož základě dochází $\mathrm{k}$ zákazu výkonu hlasovacích práv prŕímo ze zákona. Toho si ve svém komentári k BankZ všímá i Š. Elek a považuje ,za poněkud nesmyslné, aby ČNB pozastavovala výkon hlasovacích práv, když je jejich výkon již zakázán zákonem“. ${ }^{29} \mathrm{Ve}$ vymezených př́ípadech ČNB o pozastavení akcionářských práv rozhodnout musí a není jí poskytnut žádný prostor pro správní uvážení.

Podobná úprava se nachází i v PojZ. Podle § 24 PojZ potřebuje předchozí souhlas ČNB osoba nebo osoby jednající ve shodě před nabytím nebo zvýšením kvalifikované účasti nebo $\mathrm{v}$ prípadě, že se tuzemská pojištovna stane jejich ovládanou osobou.

Osoba nebo osoby jednající ve shodě, které nabyly kvalifikovanou účast nebo zvýšily svoji účast bez souhlasu ČNB, nemohou vykonávat hlasovací práva spojená s takto nabytou účastí, a to do doby udělení tohoto souhlasu - ani v tomto se úprava v PojZ od BankZ neliší.

Oproti BankZ však PojZ řeší situaci, kdy by na valné hromadě hlasoval ten, kdo má v důsledku nedostatku souhlasu ČNB zákaz hlasovat. Ust. § 26 odst. 2 PojZ stanoví, že ČNB podá návrh na vyslovení neplatnosti usnesení valné hromady tuzemské pojiš̌ovny, jestliže je v rozporu se zákonem, ohrožuje finanční stabilitu tuzemské pojištovny nebo jinak poškozuje účastníky pojištění, zaměstnance tuzemské pojištovny, její věřitele nebo menšinové akcionáře, a to ve lhůtě 30 dnů ode dne jejího konání. V druhé větě téhož odstavce se stanoví, že ČNB není povinna podat návrh na vyslovení neplatnosti usnesení valné hromady tuzemské pojišt’ovny, pokud hlasování osob uvedených v odstavci 1 nemohlo ovlivnit přijetí usnesení valné hromady nebo takto přijaté usnesení není v rozporu se zákonem, neohrožuje finanční stabilitu tuzemské pojišt’ovny ani jinak nepoškozuje účastníky pojištění, zaměstnance tuzemské pojištovny, její věřitele nebo menšinové akcionáře. Osobami uvedenými v odstavci 1 jsou právě osoby, které nemohou vykonávat hlasovací práva pro nedostatek souhlasu ČNB s nabytím kvalifikované účasti. A contrario vyplývá, že ČNB podat návrh na vyslovení neplatnosti usnesení

29 Viz LIŠKA - DŘEVÍNEK - KOTÁB - RÝDL, c. d., s. 246. 
valné hromady může i v případě, že na valné hromadě hlasovaly osoby, které k nabytí kvalifikované účasti neměly souhlas ČNB a z tohoto důvodu nemohly vykonávat hlasovací práva. Tím se rozšiřuje okruh subjektů, které se mohou domáhat zrušení usnesení valné hromady pro rozpor s právními předpisy. ${ }^{30}$ Tím je dána aktivní legitimace ČNB k podání žaloby k civilnímu soudu. Jde o zcela specifický př́pad, kdy správní orgán podává civilní žalobu ve veřejném zájmu.

Jak BankZ, tak PojZ spojuje s nabytím či zvýšením kvalifikované účasti bez vyžadovaného předchozího souhlasu ČNB typické veřejnoprávní důsledky. Nabytí nebo zvýšení kvalifikované účasti na bance anebo ovládnutí banky bez předchozího souhlasu ČNB podle $\S 20$ odst. 3 BankZ je přestupkem jak fyzických osob, tak i právnických a podnikajících fyzických osob. V obou př́padech lze pachateli přestupku uložit pokutu do dvojnásobku výše neoprávněného prospěchu. $V$ př́ípadě, že výši prospěchu nelze zjistit, lze fyzické a podnikající fyzické osobě uložit pokutu do 130 mil. Kč a právnické osobě do výše $10 \%$ ročního obratu.

\subsection{DŮSLEDKY PORUŠENÍ § 21 ODST. 6 A 7 ZRTV}

Podíl v právnické osobě, která je provozovatelem rozhlasového nebo televizního vysílání, lze podle $\S 21$ odst. 6 , resp. 7 převádět na třetí osoby po předchozím souhlasu RRTV. Jaké jsou důsledky převedení podílu bez předchozího souhlasu RRTV? ZRTV s nedostatkem souhlasu nespojuje žádné soukromoprávní důsledky. Př́ípadnou neplatnost převodu by bylo možné dovodit toliko z obecných ustanovení OZ.

ZRTV však s nedostatkem souhlasu spojuje veřejnoprávní důsledky v oblasti přestupkového práva. V § 60 odst. 5 ZRTV stanoví, že provozovatel vysílání nebo provozovatel převzatého vysílání se dopustí přestupku tím, že poruší omezení některých jednání uvedených v $\S 21$ odst. 6 a 7. Odkazovaná ustanovení vyžadují souhlas RRTV $\mathrm{k}$ převodu podílu $\mathrm{v}$ právnické osobě provozovatele vysílání. Za tento přestupek pak lze uložit pokutu od 20 tis. do 50 mil. Kč. Problémem takto formulované skutkové podstaty přestupku je, že podíl nepřevádí provozovatel, který je právnickou osobou, ale vždy jeho společník, snad s výjimkou př́padů, kdy by byl provozovatel vlastníkem svých vlastních účastnických cenných papírů (akcií). Předmětné sankční ustanovení tak nemírí na toho, kdo provádí právní jednání bez potřebného souhlasu, ale osobu, která toto jednání nemůže ovlivnit, a je proto jen stě̌̌í aplikovatelné. Pachatelem přestupku by měl být společník právnické osoby, který bez souhlasu RRTV převádí podíl v právnické osobě, která je provozovatelem vysílání, a nikoli samotná právnická osoba.

Při studiu komentářové literatury vztahující se § 21 ZRTV však můžeme narazit i na názory, které smysl veřejnoprávních sankcí v př́ípadě nedostatku souhlasu k právnímu jednání zpochybňují zcela: „Pokud by k takovému převodu (převod podílu ve společnosti provozovatele, pozn. autora) došlo bez souhlasu Rady, byl by totiž absolutnè neplatný a pohliželo by se na něj, jako by k němu vůbec nedošlo. Z tohoto důvodu je tedy nesmyslné sankční ustanovení obsažené v § 60 odst. 6 písm. a) zákona, které umožňuje Radě udělit pokutu až do výše 5000000 Kč v prípadě, že bude převeden podíl ve společnosti

30 Srov. $\S 428$ ZOK. 
provozovatele bez souhlasu Rady, nebot'k takovému převodu bez souhlasu Rady nemůže nikdy dojit, nebot' je takový převod neplatný. “ ${ }^{1} \mathrm{~K}$ tomuto inovativnímu názoru lze snad dodat pouze to, že ani př́ípadná absolutní neplatnost právního jednání (kterou nesmíme zaměňovat se zdánlivostí) neznamená, že se právní jednání neodehrálo a že nemohla být naplněna skutková podstata přestupku. Veřejnoprávní důsledky nedostatku souhlasu nastávají nezávisle na důsledcích soukromoprávních.

\subsection{DU゚SLEDKY PORUŠENÍ § 13 ZOHS}

Zřejmě nejkomplexněji k problematice nedostatku souhlasu správního orgánu k právnímu jednání přistupuje zákon o ochraně hospodářské soutěže. Ten vyžaduje souhlas k některým spojením soutěžitelů. ${ }^{32}$ Provedením spojení bez dostatečného souhlasu se zákon zabývá v $§ 18$ odst. 5. Toto ustanovení počítá se dvěma situacemi: a) ke spojení došlo v rozporu s pravomocným rozhodnutím ÚOHS, anebo b) bylo uskutečněno spojení, aniž byl podán návrh na zahájení o povolení spojení. V obou těchto př́ípadech ÚOHS rozhodne o opatřeních nezbytných k obnově účinné soutěže na relevantním trhu. Za tím účelem podle předmětného ustanovení ÚOHS zejména uloží soutěžitelům povinnost prodat soutěžitele nebo jeho část, nad nímž získali možnost kontroly, anebo povinnost zrušit smlouvu, na jejímž základě ke spojení došlo, př́ípadně provést jiná přiměřená opatření, která jou nezbytná k obnově účinné soutěže na relevantním trhu. ZOHS v $§ 15$ odst. 5 dále stanoví, že uložení opatření $\mathrm{k}$ obnově soutěže nevylučuje souběžné uložení pokuty podle příslušných ustanovení zákona.

Řešení zvolené v ZOHS je dle mého názoru ukázkou legislativně dobře zvládnutého řešení nedostatku souhlasu orgánu veřejné správy k provedení určitého právního jednání, v tomto př́ípadě právního jednání, jehož důsledkem je spojení soutěžitelů. Zákon takové právní jednání neprohlašuje za neplatné, nýbrž správnímu orgánu umožnuje uložit opatření, která mají vést k obnovení původního stavu. Zákon nehovoří o neplatnosti právního jednání nebo spojení soutěžitelů, jejíž prohlášení je, jak jsem již naznačil, těžké dosáhnout, ale snaží se o to, aby soutěžitel sám protiprávní stav napravil prostředky soukromého práva - zrušil smlouvy, prodal soutěžitele, nad nímž získal kontrolu atd. Nesplnění opatření uložených ÚOHS podle $§ 18$ odst. 5 má veřejnoprávní důsledky a je přestupkem, za který je možné uložit velmi vysokou pokutu. Fyzické osobě jako soutěžiteli může být v tomto př́padě uložena pokuta do 10 mil. Kč, právnické osobě nebo podnikající fyzické osobě jako soutěžiteli se uloží pokuta do 100 mil. Kč nebo $10 \%$ z čistého obratu dosaženého za poslední ukončené účetní období

Spojení soutěžitelů bez vyžadovaného povolení ÚOHS je navíc samo o sobě přestupkem a uložení opatření podle $\S 18$ odst. 5 nevylučuje uložení správního trestu pokuty. Soutěžitelům může být za tento přestupek uložena pokuta ve stejné výši jako $\mathrm{v}$ předešlém př́ípadě.

31 Viz ROZEHNAL, A. Zákon o provozování rozhlasového a televizního vysilání. Komentár̆. 2. vyd. Praha: Wolters Kluwer, 2011, s. 72.

32 Viz $§ 13$ ZOHS. 
Př́iklady z pozitivního práva ukazují, že zákonodárce s nedostatkem souhlasu správního orgánu $\mathrm{v}$ zákonem vyžadovaných případech spojuje různé důsledky. Přitom se ukazuje, že zvolené řešení není vždy nejvhodnější.

Pravděpodobně nejproblematičtějš́ je otázka platnosti či neplatnosti právního jednání učiněného bez požadovaného souhlasu správního orgánu. Otázka platnosti právního jednání spadá do sféry soukromého práva, při nedostatku souhlasu správního orgánu je však př́ipadná neplatnost právního jednání důsledkem porušení práva veřejného. Největším úskalím neplatnosti právního jednání, a to i v př́ípadě, že by se jednalo o neplatnost absolutní, je, že neplatnost právního jednání může prohlásit pouze soud. Domnívám se, že pouhé konstatování neplatnosti v zákoně, jako to činí např. § 16 odst. 3 BankZ, je nedostatečné. Takové právní jednání je sice ex lege neplatné, to však samo o sobě nestačí, jsem toho názoru, že je žádoucí, aby neplatnost autoritativně prohlásil orgán veřejné moci. Další problém spočívá v tom, že neplatnost může být prohlášena pouze $\mathrm{v}$ řádně zahájeném občanském soudním řízení. Domnívám se, že správní orgány nemají aktivní legitimaci k podání návrhu na určení neplatnosti právního jednání. Důsledkem neplatnosti právního jednání je, že mezi jeho stranami nevznikl žádný závazek, a to, co si jeho strany mezi sebou plnily, má povahu bezdůvodného obohacení. Jak ale soukromoprávně, bez veřejnoprávního donucení, přimět strany neplatného právního jednání, aby vrátily, co mezi sebou plnily a obnovily tak výchozí stav, pokud jim nastalý protiprávní stav vyhovuje?

Jako mnohem efektivnější se jeví postihovat právní jednání učiněné bez potřebného souhlasu správního orgánu prostředky, které jsou veřejnému právu vlastní. Provedení právního jednání bez vyžadovaného souhlasu by v prvé řadě mělo být vždy považováno za správní delikt - přestupek, za který je možno uložit správní trest, zejména pokutu, kterou je možné vymáhat $\mathrm{v}$ exekučním řízení. Bohužel ne všechna právní jednání provedená bez potřebného souhlasu správního orgánu jsou kvalifikována jako přestupek a zákon s nimi nespojuje ani žádné jiné veřejnoprávní důsledky. Připomeňme, že jednou z rolí přestupkového práva je i role preventivní a hrozba peněžní pokuty může preventivně působit mnohem lépe než hrozba těžko vymahatelné neplatnosti.

Dalším vhodným prostředkem, jak veřejnoprávní cestou postihovat právní jednání učiněná bez souhlasu správního orgánu, je možnost ukládání nápravných opatření, jejichž cílem je obnovení výchozího stavu. Možnost správního orgánu uložit nápravné opatření je dle mého názoru v prrípadě porušení veřejného práva mnohem vhodnější než postihovat právní jednání neplatností. Samotná neplatnost totiž ještě nemusí znamenat, že dojde k nápravě protiprávního stavu. Neprovedení nápravných opatření by opět mělo být kvalifikováno jako přestupek.

V př́ípadě závažného porušení zákazu provádět určitá právní jednání bez souhlasu př́slušného správního orgánu by měl mít správní orgán výslovně stanovenou možnost odebrat či pozastavit platnost oprávnění, které umožňuje podnikání v př́islušné oblasti.

Pro srovnání: V některých případech zvláštní předpisy umožňují převedení veřejnoprávního oprávnění (zejména koncese) na jinou osobu na základě smlouvy, přičemž převod oprávnění je podmíněn souhlasem př́slušného správního orgánu a nedostatek 
souhlasu je sankcionován neplatností převodu. ${ }^{33} \mathrm{~V}$ těchto případech neplatnost prohlášená zákonem nevytváří žádný problém, nebot' veřejnoprávní oprávnění, které má být převedeno, vzniká vždy za podmínek stanovených zákonem, u koncese rozhodnutím správního orgánu (propůjčení koncese). Není proto pojmově možné, aby k převodu veřejnoprávního oprávnění došlo bez splnění podmínek, které jsou stanoveny veřejným právem. Rozdíl oproti předchozím př́kladům spočívá $\mathrm{v}$ tom, že se smlouvou o převodu veřejnoprávního oprávnění spojuje účinky veřejné právo, a nikoli právo soukromé, jako je tomu např́ílad u smlouvy o převodu obchodního závodu. V takových př́ípadech nedochází ke střetu veřejného a soukromého práva a není třeba, aby neplatnost právního jednání prohlašoval soud. Vzájemná práva a povinnosti, které si strany smlouvy převodu veřejnoprávního oprávnění ujednaly, nejsou pro veřejné právo v těchto případech relevantní. Správněprávní odpovědnost za uzavření smlouvy bez souhlasu správního orgánu přesto není vyloučena - uzavření smlouvy o převodu veřejnoprávního oprávnění bez souhlasu správního orgánu může být kvalifikováno jako přestupek. ${ }^{34}$

\section{ZÁVĚR}

Normy veřejného práva mohou výkon celé řady lidských činností podmiňovat vydáním dovolujícího správního aktu, bez kterého by byl výkon takové činnosti v rozporu s právem. Většina takových činností se ve vnějším světě projevuje přímo, a nepotřebuje, aby této činnosti právo přiznávalo další účinky. Veřejnoprávní regulace se tak snaží, pokud možno, omezit negativní dopady některých činností. Povolení správního orgánu tak je vyžadováno například ke kácení dřevin, které splňující určité parametry. K pokácení dřeviny dojde, aniž by řezání pily právo přiznávalo jakékoli účinky. U právního jednání je tomu jinak. To jeho strany činí právě proto, aby vyvolalo účinky právem mu přiznané. Bez těchto účinkủ by nešlo o „právní jednání“, ale pouze o ,jednání“, jehož význam by byl nanejvýše symbolický. Právní jednání je doménou soukromého práva, které upravuje právní jednání jako takové, tedy způsobilost $\mathrm{k}$ němu, jeho náležitosti i důsledky jeho vad, jakož v naprosté většině př́padů i jeho účinky. Právní jednání jako horizontální projev autonomie vůle je přesto v některých př́ípadech svrchu omezen veřejným právem, které provedení právního jednání může vázat na vydání dovolujícího správního aktu.

Musíme si uvědomit, že $\mathrm{v}$ těchto př́padech nedochází pouze $\mathrm{k}$ omezení možnosti právně jednat, ale i k omezení dalších práv, zejména práva vlastnického, pokud je zákonem omezena dispozice s vlastním majetkem, či právo účastnit se na podnikání právnických osob, pokud zákon omezuje nabytí kvalifikované účasti v právnických osobách. Kritériem, které specifikuje př́ípady, v kterých je vyžadováno vydání dovolujícího správního aktu, není pouze samotná povaha právního jednání (např. prodej obchodního

33 Viz např. převod stanovení průzkumného území podle $\S 4$ odst. 5 zákona č. 62/1988 Sb., o geologických pracích a o Českém geologickém úruadu nebo převod př́ídělu rádiových kmitočtů podle zákona č. 127/2005 Sb., o elektronických komunikacích.

34 Viz např. § 118 odst. 6 písm. a) zákona o elektronických komunikacích. 
závodu), ale navíc i určitá specifická vlastnost subjektu právního jednání (např. veřejnoprávní oprávnění $\mathrm{k}$ regulované činnosti nebo významné postavení $\mathrm{v}$ hospodářské soutěži).

Podmiňování právního jednání vydáním dovolujícího správního aktu je př́ípustné pouze $\mathrm{v}$ těch př́padech, kde by zcela volné, neregulované provádění takových právních jednání mělo za následek ohrožení důležitých právem chráněných zájmů, např. stabilitu finančních trhů nebo volné hospodářské soutěže. Lze říci, že v určitých odvětvích převažuje veřejný zájem nad jinak prosazovanou autonomií právního jednání v soukromoprávních vztazích. Naopak podmiňovat každý převod obchodního závodu souhlasem veřejné správy by $\mathrm{v}$ testu proporcionality obstát nemohlo.

Střet soukromého a veřejného práva se naplno projevuje $\mathrm{v}$ př́ípadě nedostatku souhlasu správního orgánu k právnímu jednání. Pokud jde o neoprávněně pokácený strom, je zřejmé, že prohlášení pokácení stromu za neplatné je zcela zbytečné, nebot' to vzrostlý strom neobnoví. Nastoupit musí správní represe, která také strom neobnoví, ale mimo jiné by měla plnit preventivní roli a odradit další osoby od protiprávního jednání. Ač se to může zdát jako absurdní, právní jednání provedené bez souhlasu správního orgánu není v tomto směru tolik odlišné. Zdá se totiž, že samotné prohlášení takového právního jednání zákonem za neplatné se mine účinkem. Nastává problém s tím, zda se jedná o neplatnost absolutní či relativní, jaký orgán může neplatnost prohlásit a kdo se jí může dovolávat. I když dojde $\mathrm{k}$ autoritativnímu prohlášení „neoprávněného“ právního jednání za neplatné, není zaručeno, že skutečně dojde k obnovení výchozího stavu. Problém spočívá také v tom, že soukromoprávní normy nepočítají se situací, že by právní jednání bylo podmíněno souhlasem správního orgánu.

Právní jednání bez souhlasu správního orgánu, tam, kde je vyžadování je jednoznačné porušení veřejného práva. Domnívám se, že takové právní jednání by mělo být v prvé řadě postihováno právními prostředky, které jsou veřejnému právu vlastní. Jako nejefektivnější se mi jeví ukládání opatření sledujících obnovení výchozího stavu spojené se správním trestáním. Jako krajní řešení porušení zákazu právně jednat bez souhlasu správního orgánu by správní orgány měly mít možnost v př́ípadech, kde je to účelné, odebrat regulovaným subjektům veřejnoprávní oprávnění (licenci), která jim umožňuje působit $\mathrm{v}$ regulovaných odvětvích. Jednoduše řečeno, veřejné právo by se nemělo spoléhat na to, že nedostatek souhlasu správního orgánu k právnímu jednání vyřeší právo soukromé. Na soukromé právo v tomto směru nelze spoléhat, vždyt' občanský zákoník v hned v § 1 odst. 1 říká, že uplatňování soukromého práva je nezávislé na uplatňování práva veřejného. Pokud některé normy veřejného práva podmiňují provedení právního jednání vydáním dovolujícího správního aktu a zároveň neřeší důsledky absence takového aktu, lze tyto normy označit za imperfektní.

Cílem tohoto článku bylo v prvé řadě ukázat, že orgány veřejné správy mohou svou působnost vykonávat $\mathrm{v}$ některých př́ípadech i tím, že vydávají správní akty, které opravňují jejich adresáty právně jednat a vyvolávat tím účinky v oblasti soukromého práva, ačkoli právní jednání je zásadně možné činit zcela autonomně a nezávisle na orgánech veřejné správy. Na př́íkladu správních aktů podmiňujících právní jednání lze dále demonstrovat rozdíly mezi právem veřejným a soukromým. I přes snahy o určitou relativizaci dělení práva na soukromé a veřejné se ukazuje, že toto dělení má stále svůj 
smysl. Metody, které užívá právo veřejné a právo soukromé, jsou natolik rozdílné, že některé jejich průniky mohou být problematické, obzvlášt pokud $\mathrm{k}$ nim zákonodárce neprristupuje s potřebnou rozvahou a nedomyslí veškeré souvislosti.

Mgr. Pavel Kopecký

Právnická fakulta Univerzity Karlovy

pa.kopecky@seznam.cz 